WARSZTATY Z GEOGRAFII TURYZMU

ISBN 978-83-7969-262-0 $\quad$ s. 131-144

http://dx.doi.org/10.18778/7969-262-0.09

Barbara PISARSKA

Szkoła Główna Turystyki i Rekreacji w Warszawie

\title{
W POSZUKIWANIU IDEI ROZWOJU TURYSTYKI; „PRZESZŁOŚĆ - PRZYSZŁOŚCI”
}

\section{Wstęp}

Idea to jedno z głównych pojęć filozoficznych, które oznacza myśl przewodnią, koncepcję wyznaczającą cel i kierunek działania oraz twórczości naukowej czy artystycznej (pl.wikipedia.org). Taką rolę w dużej mierze spełniało przesłanie „Przeszłość - przyszłości”, które umieszczono nad wejściem do puławskiej Świątyni Sybilli. W tej budowli, nawiązującej do panującego wówczas stylu klasycystycznego jako przejawu zainteresowania się światem antycznym, otwarto w 1801 r. pierwsze polskie muzeum. Miało ono stanowić świątynię pamięci o dawnej chwale Rzeczypospolitej; przechowywano tu m.in. miecze ofiarowane królowi Władysławowi Jagielle i księciu Witoldowi pod Grunwaldem oraz szablę króla Stefana Batorego. W drugim specjalnie wybudowanym w tym celu obiekcie muzealnym z 1809 r. - Domku Gotyckim - przechowywano Damę z gronostajem Leonarda da Vinci oraz Autoportret Rafaela. Kolekcja ta dała początek Muzeum Czartoryskich, które funkcjonuje w Krakowie, począwszy od 1876 r. (Polska.., 1974, http://ludzie tworzaswiat; http://www.muzeum.szczecin.pl).

Warto wspomnieć o okolicznościach wyprzedzających czasowo założenie muzeum przez księżnę Izabelę Czartoryską (1748-1835). Należała ona wraz mężem (Adamem Kazimierzem) do grona najzamożniejszych magnatów, którzy chociaż późno - bo tuż przed rozbiorami kraju - zainteresowali się sprawami publicznymi. Wcześniej prowadzili bujne życie towarzyskie, 
podróżowali po Europie, budowali założenia pałacowo-ogrodowe. Czartoryscy podczas Sejmu Wielkiego związani byli ze Stronnictwem Patriotycznym, wspierali powstanie kościuszkowskie, a potem listopadowe, co przypłacili konfiskatą majątków na Litwie, Podolu i Wołyniu. Po przeprowadzeniu się z Warszawy (z Powązek) do Puław (od 1783 r.), stworzyli w nich swoiste "Ateny polskie”, czyli ośrodek życia kulturalnego. Przyjeżdżali tam, a nawet mieszkali latami - tacy twórcy Oświecenia, jak: biskupi Ignacy Krasicki i Jan Paweł Woronicz, Stanisław Staszic, Julian Ursyn Niemcewicz, Franciszek Dionizy Kniaźnin, Franciszek Karpiński, Jan Piotr Norblin (nadworny malarz). Goszczono również Józefa i Stanisława Augusta Poniatowskich, Fryderyka Augusta i Aleksandra I (http://ludzietworzaswiat).

Aby naświetlić tragizm położenia zdrowej tkanki polskiego narodu, trzeba wspomnieć o tym, że nawet tak zdolni królowie, jak Stefan Batory $(1576-1586)^{* 1}$ oraz Jan III Sobieski (1674-1696)* nie zdołali ukrócić samowoli magnackiej. O ile August II Mocny (1697-1733)* utrzymywał w Polsce porządek, to za Augusta III (1733-1763)* zapanowała pełna anarchia życia publicznego. Stanisław August Poniatowski (1764-1795)* ze względu na zależność od carycy Katarzyny II dopuścił do I rozbioru Rzeczypospolitej (1772 r.). Próbował on ratować sytuację, kierując Obozem Reform, a więc doprowadzając do obrad Sejmu Wielkiego (1788-1792), który uchwalił Konstytucję 3 Maja (1791 r.). Reakcją na II rozbiór (1793 r.) było powstanie kościuszkowskie, które upadło. Następnie król (wbrew zdrowemu rozsądkowi) przystąpił do przeciwstawnego sobie wcześniej obozu Targowicy, co oznaczało III rozbiór kraju (ŁUKASZEWICZ 1980).

Jak więc widać, Polska utraciła suwerenność przez zobojętnienie na sprawy publiczne, lekceważenie pierwszych symptomów chorób społecznych, a skupienie się na prywacie. Współcześnie istnieją jeszcze tego rodzaju zagrożenia, jak: bezideowość oraz „spłaszczenie” tożsamości narodowej przez bezkrytyczne upowszechnianie globalizmu. Wobec powyższego potrzebna jest dziś refleksja nad sensem i aktualnością przesłania „Przeszłość - przyszłości", w związku z czym autorka pragnie poruszyć następujące tematy:

- Zasługi wybitnych jednostek dla idei poznania ziemi ojczystej podczas zaborów;

- Upowszechnienie turystyki poprzez organizacje krajoznawczo-turystyczne;

- Konkretyzacja idei rozwoju turystyki w XXI w.

${ }^{1}$ W nawiasach z gwiazdką oznaczono okres sprawowania władzy królewskiej. 


\section{Zasługi wybitnych jednostek dla idei poznania ziemi ojczystej podczas zaborów}

Jak zaznaczają Z. KRUCZEK, A. KUREK, M. NOWACKI (2010, s. 30) oraz W. LIPNIACKI (1985, s. 41) - w Polsce, podobnie jak w Europie, prawdziwy rozwój krajoznawstwa nastąpił od połowy XVIII w. Od tego okresu zaczęła krystalizować się krajoznawcza myśl wychowawcza. Na gruncie oświeceniowego znawstwa i zamiłowania do zabytków przeszłości wyróżniały się w działalności krajoznawczej dwa nurty:

1) zbieranie i popularyzowanie wiadomości o kraju;

2) krajoznawstwo edukacyjne.

Ad 1. Zbieranie i popularyzowanie wiadomości o kraju było niezbędne do administrowania nim i kierowania jego rozwojem gospodarczym. Słusznie uznawano już wtedy, że lustracja kraju powinna wyprzedzać wydawanie ważnych rozporządzeń. Służyły jej przedsięwzięcia, które realizowali następujący twórcy Oświecenia:

- Michał Mniszech (1748-1806), autor koncepcji muzeów krajowych (Myśli wzzględem założenia Musaeum Polonicum z 1775 r.);

- Izabela Czartoryska (1748-1835), realizatorka wspomnianego pierwszego muzeum pamiątek narodowych (1801 r.) w Puławach;

- Stanisław Kostka Potocki (1755-1821), założyciel Towarzystwa Przyjaciół Nauk (TPN) w Warszawie w 1800 r.; swoje zbiory w Wilanowie udostępnił od 1804 r.; kierując od 1810 r. oświeceniem publicznym, rozbudował sieć szkół elementarnych;

- Tadeusz Czacki (1765-1813), współzałożyciel TPN - zainicjował opracowanie mapy hydrograficznej Polski i Litwy; jako działacz oświatowy założył Liceum Krzemienieckie w 1805 r.;

- Karola de Perthees (1739-1815), kronikarz królewski - autor opisu krajoznawczego pt. Geograficzno-statystyczne opisanie parafiów Królestiva Polskiego z 1791 r.;

- Bernardo Bellotto (1720-1780), zwany Canalettem - autor serii dwudziestu kilku widoków Warszawy (dokumentacja stolicy z lat 17671780);

- Zygmunt Vogel (1764-1826), autor albumu prowincji pt. Zbiory widoków sławniejszych pamiątek narodowych jako też zwoalisk zamków, świątyń, nagrobków, starowniejszych budowli i miejsc pamiatkowych w Polsce z natury rysowanych (krócej Podróże malownicze - 1806 r.). 
Wymienieni twórcy zainspirowali całą plejadę innych na rzecz dokumentowania śladów przeszłości ojczyzny, szczególnie po utracie państwowości.

Ad 2. Krajoznawstwo edukacyjne to nurt ściśle wiążący się z działalnością Komisji Edukacji Narodowej (1773-1794), która dysponowała funduszami po skasowanym przez papieża zakonie jezuitów. Głównym celem działań edukacyjnych było wychowanie patriotyczne. O nowym podejściu najbardziej świadczyło to, że językiem uprzywilejowanym był język polski. Nacisk kładziono nie tylko na emocjonalne pozytywne nastawienie do tego co polskie, ale na przygotowanie rozumu do zarządzania i na kształcenie umiejętności praktycznych.

O docenieniu krajoznawstwa i turystyki jako drogi do postawy patriotycznej świadczy powtarzana wtedy często maksyma, aby Polacy „naprzód znali swój kraj, a potem sąsiedzkie bliskie". Podobny sens miał apel skierowany przez ks. Stanisława Staszica do młodzieży, "aby nikt nie ubiegł jej w poznaniu własnej ojczyzny" (KRUCZEK, KUREK, NOWACKI 2010, s. 31-32). To silne dążenie do poznania własnego kraju czy regionu stanowiło fundament krajoznawczej myśli wychowawczej. Za jej najwybitniejszego reprezentanta uznaje się Stanisława Staszica (1755-1826). Od młodości pasjonowało go zarówno poznawanie świata przyrody, jak i ludzi; wędrował po kraju i za granicą (CZARNOWSKi 2006, s. 13-23). Był to:

- prawdziwy uczony (filozof, przyrodnik, geolog; 18 lat prezesował TPN 1808-1826);

- mąż stanu (czołowy reprezentant obozu reform, zwolennik moralnego wychowania);

- działacz gospodarczy (przygotował projekt rozwoju Staropolskiego Okręgu Przemysłowego i wielu kopalń);

- działacz oświatowy (jako członek KEN utworzył kilka szkół zawodowych, Szkołę Akademiczno-Górniczą w Kielcach - 1816 r., Instytut Agronomiczny w Marymoncie - zaczątek późniejszej SGGW; współorganizował też uniwersytet $\mathrm{w}$ Warszawie; zalecał wprowadzenie wycieczek do programów nauczania wszystkich typów szkół).

Jak można zorientować się po przedziale lat życia wyżej i niżej wymienionych postaci historycznych, większość z nich działała na pograniczu różnych wydzielanych głównie w XX w. okresów. Stanowili oni często „ogniwa pośrednie między starymi a nowszymi czasy”, co gwarantowało ciągłość określonych idei w sztafecie pokoleń. Oni ją zainicjowali, co W. LIPNIACKI 
(1985, s. 41) podkreślił, pisząc, że „krajoznawstwo u swej kolebki postęp zawdzięczało wyłącznie wysiłkom jednostek".

W romantyzmie, utożsamianym z zainteresowaniem przyrodą, średniowieczem i ludem, w krajoznawstwie wyróżnia się takie nurty i ich przedstawicieli, jak:

1) krajoznawstwo wycieczkowe - za jego maksymę ideową można uznać słowa z wiersza Wieś Stanisława Jachowicza (1796-1867): „Cudze chwalicie, swego nie znacie, sami nie wiecie, co posiadacie”; nawiązują one wyraźnie do zaleceń Stanisława Staszica;

a) Julian Ursyn Niemcewicz (1758-1841) - kadet ze Szkoły Rycerskiej, mąż stanu, historyk, literat, znawca ziem polskich i obcych; współpracownik T. Kościuszki oraz S. Staszica (z Obozu Reform, KEN i TPN). Nauczał historii poprzez powszechnie czytane Śpiezoy historyczne (1816 r.), a także Podróże historyczne po ziemiach polskich między rokiem 1811 a 1828 odbyte (1858 r.), Pamiętniki czasów moich i wiele innych utworów. Będąc autorytetem dla sobie współczesnych - wytykał wady narodowe i wskazywał sposoby naprawy błędów (CzARNOWSKI 2006, s. 24-36);

b) Wojciech Jastrzębowski (1799-1882) - przez 22 lata pracował w założonym przez S. Staszica Instytucie Agronomicznym jako profesor nauk przyrodniczych. Wychował setki następców, zaszczepiając wiedzę i miłość do rodzimej przyrody poprzez wycieczki w okolice Warszawy, nad Narew, Bug, w Góry Świętokrzyskie, na Jurę czy Lubelszczyznę (CZARNOWSKI 2006, s. 37-44);

c) Oskar Kolberg (1814-1890), muzyk współpracujący z malarzami i poetami - znał J. Elsnera, F. Chopina, S. Moniuszkę, W. Gersona, W. E. Radzikowskiego, C.K. Norwida i T. Lenartowicza. Dochody czerpał z pracy księgowego, a przeznaczał je na podróże badawcze i wydawanie 34 tomów Pieśni ludu polskiego, w których oddał całość żywej sztuki ludowej (m.in. 12,5 tys. pieśni ludowych z różnych regionów i obrazy etnograficzne) (CZARNOWSKI 2006, s. 55-65);

2) nurt poetycko-opisowy:

a) Seweryn Goszczyński (1801-1876) - utworem Dzienniki podróży do Tatrów (1853 r.) wprowadził do literatury tematykę góralską;

b) Wincenty Pol (1807-1872) - geograf i poeta, określany profesorem krajoznawstwa na Uniwersytecie Jagiellońskim; organizował dla studentów zajęcia w Puszczy Niepołomickiej, Tyńcu, Beskidach i Tatrach. Był pierwszym polskim badaczem Sudetów i Kresów, ale jego 
najbardziej kompleksowa praca naukowa to Rzut oka na pótnocne stoki Karpat i przyległe krainy (1851 r.). Najsłynniejsze utwory literackie to Pieśń o ziemi naszej (1843 r.) oraz Obrazy życia i natury (1869-1870) jako pełne optymizmu i miłości do ziemi ojczystej krzewiły wiedzę i ducha narodowego, co było wtedy sensem powołania twórców - strofy te znały na pamięć pokolenia naszych przodków (CZARNOWSKI 2006, s. 45-54);

c) Teofil Lenartowicz (1822-1893) - określany „lirnikiem mazowieckim” $\mathrm{z}$ racji utworu Echa nadwiślańskie, ale cenne są też dzieła Polska ziemia i Rytmy narodowe;

Pod wpływem pokroju ludzi powyżej przedstawionych - inni zaczęli działać, tworząc w latach 1816-1830 około 40 różnych związków i kół, z których najbardziej znane do dziś są: Towarzystwo Filomatów (z gr. przyjaciół nauk) i Towarzystwo Filaretów (z gr. przyjaciół cnoty). Był to przejaw „przeciwdziałania procesom wynarodowienia"; tak Z. KRUCZEK, A. KUREK, M. NOWACKI (2010, s. 34) określili trzeci nurtu w romantyzmie.

Reasumując tę część, autorka pragnie podkreślić wiekopomną rolę prekursorów krajoznawstwa, jak utytułował A. CZARNOWSKI (2006, s. 5) S. Staszica, J.U. Niemcewicza, W. Jastrzębowskiego, W. Pola i O. Kolberga. Z. KULCZYCKI (1977, s. 28) szczególnie wyróżnił dwóch pierwszych z nich, pisząc, że "Staszicowskie poznanie przyrody i Niemcewiczowskie zamiłowanie do historii stały się fundamentem przyszłego polskiego krajoznawstwa, a ich praktyka osobistego poznania wszystkiego, co nowe i ciekawe, utorowała szlaki naszej turystyki".

\section{Upowszechnienie turystyki poprzez organizacje krajoznawczo-turystyczne}

Związani z górami z terenu Galicji najbardziej światli ludzie z kręgów nauki, sztuki oraz władz polityczno-ekonomicznych założyli w 1873 r. Galicyjskie Towarzystwo Tatrzańskie. Po to, aby mogło ono zrzeszać Polaków z trzech zaborów, zmieniono jego nazwę na Towarzystwo Tatrzańskie (1874-1922); w wolnej Polsce działało jako Polskie Towarzystwo Tatrzańskie (1922-1950). Początkowo miało ono charakter elitarny, ale z czasem jego motorem napędowym stała się inteligencja pracująca (LEWAN 2004, s. 28-36).

Na tle dynamicznie działających członków Towarzystwa wyróżniali się: dr Tytus Chałubiński (1820-1889) oraz Walery Eliasz Radzikowski (1841 
-1905). Pierwszy z nich to lekarz i botanik z Warszawy, któremu Zakopane zawdzięcza karierę uzdrowiska. Przyciągał on tam pacjentów, naukowców i artystów, pamiętając również o zabezpieczeniu losu górali. Dla ludzi z tych wszystkich środowisk organizował wyprawy w Tatry, które stały się wzorem turystyki o tradycjach narodowych.

W.E. Radzikowski to malarz, grafik, fotograf i autor pierwszego Ilustrowanego przewodnika do Tatr, Pienin i Szczawnic (1870 r.). Zajmował się on dosłownie wszystkim: redakcją artykułów, planowaniem przebiegu szlaków, ale też ich znakowaniem $w$ terenie, organizowaniem przewodnictwa, straży ochrony przyrody, ale także odczytów, koncertów czy przedstawień teatralnych (CZARNOWSKI 2006, s. 81-104).

W autonomicznej od $1867 \mathrm{r}$. Galicji działały też inne organizacje:

- Towarzystwo Gimnastyczne „Sokół” (od 1867 r.);

- Towarzystwo Szkoły Ludowej (od 1891 r.) z Sekcją Wycieczek Ludowych i Szkolnych;

- Towarzystwo Kolonii Wakacyjnych (od 1895 r.);

- Akademicki Klub Turystyczny (od 1906 r.) założony przez M. Orłowicza we Lwowie;

- Stowarzyszenie Polskich Robotników i Robotnic "Siła” w 1908 r. w Cieszynie.

Jak widać, turystyka znajdowała swoich zwolenników w różnych środowiskach, w związku z czym w 1907 r. Rada Szkolna Krajowa wydała pierwsze pismo okólne zalecające organizowanie wycieczek szkolnych - akt przyzwolenia na upowszechnienie krajoznawstwa i turystyki (KRUCZEK, KUREK, NOWACKI 2010, s. 36, LEWAN 2004, s. 37-39).

W zaborze rosyjskim najpierw powstały: Warszawskie Towarzystwo Wioślarskie (1878 r.) i Cyklistów (1886 r.), a dopiero w 1906 r. Polskie Towarzystwo Krajoznawcze. Najbardziej zasłużeni dla założenia PTK byli:

- Kazimierz Kulwieć (1871-1943), przyrodnik, pedagog, który od 1899 r. organizował wycieczki dla członków Towarzystwa Ogrodniczego Warszawskiego; jego imię nosi dziś Centralna Biblioteka PTTK (CZARNOWSKI 2006, s. 125-133);

- Aleksander Janowski (1866-1944); organizował najpierw wycieczki dla kolegów z Kolei Warszawsko-Wiedeńskiej, a później dla gimnazjalistów, których nauczał krajoznawstwa; wydając Wycieczki po kraju (1900-1903), proponował ich trasy, ale pisał też o metodyce ich organizowania (1923) oraz o idei i pracy krajoznawczej (1930) (CZARNOWSKI 2006, s. 113-124). 
Pierwszym prezesem PTK był Zygmunt Gloger (1845-1910) - archeolog, etnograf, historyk - autor ponad 1050 różnych prac, w tym 30 książek, z których najbardziej znane są: Pieśni ludu (1892 r.), Dolinami rzek (1903 r.), Encyklopedia staropolska ilustrowana (1900-1003); tytuł jednej z prac Poznaj swój kraj (z 1907 r.) stał się od 1958 r. tytułem poczytnego czasopisma krajoznawczego. Odziedziczywszy po przodkach zamiłowanie do kolekcjonerstwa, gromadził pamiątki narodowe w Jeżewie k. Tykocina, które było miejscem spotkań elity intelektualnej (O. Kolberg, W. Jastrzębowski, H. Sienkiewicz, E. Orzeszkowa). Z. Gloger dużo uczynił na rzecz późniejszego założenia muzeum etnograficznego w Warszawie. Zmarł 15.08.1910 r. po obchodach 500-lecia Bitwy pod Grunwaldem. Na jego pomniku nagrobnym na Powązkach wyryto słowa: „Kochał Przeszłość dla Przyszłości” (CZARNOWSKI 2006, s. 66 -77). Niech podkreślenie tej paraleli stanowi dowód na sens wysiłków „kustoszy" tożsamości narodowej w latach 1801-1910.

Po odzyskaniu niepodległości w 1918 r. doszło do prężnego rozwoju krajoznawstwa i turystyki na trzech najważniejszych poziomach, tzn. w organach władzy, w szkołach oraz w organizacjach społecznych. Zdaniem autorki niniejszego opracowania - największą wagę dla przyszłości miało to, co działo się wtedy w odniesieniu do szkół. Odpowiednie urzędy sformułowały:

1) odezwę zachęcającą do zakładania domów wycieczkowych dla zbiorowych wycieczek, głównie szkolnych w Warszawie, Krakowie, Lwowie i Poznaniu;

2) apel do dyrektorów szkół o wspieranie Kół Krajoznawczych Młodzieży Szkolnej (KKMS); w 1939 r. istniało ich w kraju ponad 500, a zrzeszały one około 200 tys. młodzieży;

3) zarys systemu organizacyjnego i wychowawczego krajoznawstwa i turystyki, włącznie $z$ opracowaniem wzorcowych programów, instrukcji oraz regulaminów;

4) zasady współpracy pomiędzy władzami szkolnymi, PTK i ZHP (KRUCZEK, KUREK, NOWACKI 2010, s. 38-42, LEWAN 2004, s. 47-62).

Kadrę na potrzeby rozwoju krajoznawstwa w szkole przygotowali związani z UJ:

- prof. Ludomir Sawicki (1884-1928), uczony geograf, autor 150 książek, w tym podręczników, który na potrzeby popularyzacji wiedzy krajoznawczej napisał Elementarz geograficzny, prowadził kursy, wycieczki i odczyty; 
- Leopold Węgrzynowicz (1881-1960) - nauczyciel przedmiotów ścisłych i przyrodniczych, etnograf, działacz harcerstwa, kierował KKMS w latach 1919-1939, a później w okresie 1957-1960 r.;

- dr Stanisława Niemcówna (1891-1961), geograf metodyk, autorka Metodyki pracy w kołach krajoznawoczych młodzieży (1921 r.), działaczka harcerstwa i KKMS, zwolenniczka - jak można byłoby dziś określić zintegrowanego nauczania krajoznawstwa w szkołach.

Znaczny wpływ na środowisko nauczycieli miał Aleksander Patkowski (1890-1942) - autor Programu regionalizmu polskiego (1926 r.), który potrafił pobudzić społeczności lokalne do kultywowania specyficznych dla nich wartości.

Trzeba wyraźnie podkreślić, że największą rolę w sprawnym zarządzaniu rozwojem krajoznawstwa i turystyki w latach 1919-1939 oraz 1945-1948 odegrał dr Mieczysław Orłowicz (1881-1959) - prawnik i historyk sztuki, autor 102 przewodników i ponad 190 artykułów publikowanych w różnych czasopismach. Był geniuszem, miał zmysł organizatorski i cechy przywódcze, a przy tym wykazywał niezwykłą wrażliwość na sprawy społeczne i piękno (był animatorem fotografii krajoznawczej) (CZARNOWSKI 2006, s. 241-252).

Powszechny dostęp do turystyki w okresie po 1945 r. wynikał z demokratyzacji życia społecznego, w tym stworzenia podstaw prawnych dla rozwoju turystyki socjalnej, którą realizowały: FWP, zakłady pracy oraz różne organizacje, wśród których przodowało Polskie Towarzystwo Krajoznawczo-Turystyczne (PTTK). Powstało ono w 1950 r. z połączenia PTT, które miało wtedy 11744 członków i PTK liczącego 7400 osób (Statystyka...).

Tabela 1 odzwierciedla ilościowe zmiany, jakie zaszły w okresie 63 lat działalności tej organizacji - wielce zasłużonej dla szerzenia znajomości kraju. Przy analizie uwzględniono wszystkie lata $\mathrm{z}$ tego wielolecia, ale $\mathrm{w}$ tabeli zamieszczono tylko dane w odstępach 5-letnich. Na ich podstawie można jednak zorientować się, jaki był zasięg społecznego oddziaływania PTTK. Rósł on systematycznie, osiągając apogea w latach 70. i 80. XX w. Przez 20 lat (1969-1989) w imprezach krajoznawczo-turystycznych PTTK uczestniczyło rocznie ponad $5 \mathrm{mln}, \mathrm{w}$ tym $\mathrm{w}$ latach 1972-1980 ponad 9 mln ludzi z różnych środowisk (Roczniki... 1951-2013). Najwięcej osób przyciągnęły one w 1975 r. $(10,9 \mathrm{mln}), 1976(10,5 \mathrm{mln})$ i $1974(10,4 \mathrm{mln})$. Maksymalna liczba członków PTTK wystąpiła w 1979 r. (767,9 tys.), w 1988 (731,9 tys.) oraz w 1980 (730,9 tys.). Od roku 1990 zanotowano drastyczne spadki zarówno liczby członków PTTK, jak uczestników jego imprez. W dużej mierze wynikało to 
z likwidacji setek wielkich zakładów pracy oraz braku środków na kontynuację działalności kół i klubów w zmienionych warunkach społeczno-ekonomicznych.

Tabela 1. Liczba członków, przewodników i uczestników imprez krajoznawczo-turystycznych PTTK oraz udział wśród tych ostatnich uczestników imprez turystyki kwalifikowanej w latach 1950-2013

\begin{tabular}{|l|c|c|c|c|}
\hline \multirow{2}{*}{ Rok } & \multicolumn{2}{|c|}{ Liczba (w tys.) } & \multicolumn{2}{c|}{ Uczestnicy imprez } \\
\cline { 2 - 5 } & członków & przewodników & $\begin{array}{c}\text { krajoznawczo-tury- } \\
\text { stycznych } \\
\text { (w mln) }\end{array}$ & $\begin{array}{c}\text { turystyki } \\
\text { kwalifikowanej } \\
(\mathrm{w} \%)\end{array}$ \\
\hline 1950 & 19,1 & - & - & - \\
\hline 1955 & 141,3 & - & 0,5 & 26,3 \\
\hline 1960 & 188,8 & 2,6 & 1,2 & 33,8 \\
\hline 1965 & 250,5 & - & 2,0 & 25,3 \\
\hline 1970 & 418,9 & 11,8 & 8,5 & 20,6 \\
\hline 1975 & 543,6 & 15,0 & 10,9 & 22,1 \\
\hline 1980 & 730,9 & 17,4 & 9,0 & 25,9 \\
\hline 1985 & 691,9 & 16,2 & 9,1 & 23,2 \\
\hline 1990 & 484,6 & 16,9 & 3,9 & 36,8 \\
\hline 1995 & 98,9 & 12,2 & 1,2 & 57,3 \\
\hline 2000 & 82,5 & 13,6 & 1,1 & 62,8 \\
\hline 2005 & 62,7 & 10,2 & 1,0 & 65,6 \\
\hline 2010 & 61,7 & 8,8 & 1,0 & 68,1 \\
\hline 2012 & 62,0 & 8,5 & 0,8 & 73,4 \\
\hline
\end{tabular}

Objaśnienia: - duże różnice w danych z dwóch wymienionych źródel, wobec czego wstrzymano się z ich przytoczeniem.

Źródła: Roczniki statystyczne GUS z lat 1951-2013; "Statystyka Turystyki”, 1950-1966; ser. „Studia i Prace Statystyczne", nr 7, GUS, Warszawa.

Biorąc pod uwagę okres od powstania Towarzystwa Tatrzańskiego w 1873 r. do czasów współczesnych, należy podkreślić, że PTTK okazało się organizacją, która odniosła największy sukces w zakresie upowszechnienia turystyki w Polsce. Prawdziwe zasługi w tej mierze wiązały się z tworzeniem kół i klubów na terenie zakładów pracy (od 1955 r.) oraz w szkołach, a także stworzenie monopolu na dobre wyszkolenie przewodników, których najwięcej zarejestrowano w 1979 r. (prawie 18 tys.). Owocem trudów pracowników etatowych i działaczy społecznych PTTK są rekrutujący się spośród byłych członków i uczestników imprez - rodzice, nauczyciele, przedsiębiorcy turystyczni, którzy przekazują wiedzę i pasję krajoznawczą swoim dzieciom, uczniom i klientom. 


\section{Konkretyzacja idei współcześnie i w przyszłości}

Nawiązując do powyższych wersów autorka proponuje, aby za główne idee turystyki w XXI w. uznać:

1) trwanie przy jej istocie, którą stanowią treści krajoznawcze przekazywane zgodnie $\mathrm{z}$ celami interpretacji dziedzictwa;

2) postawienie na ekologizację turystyki masowej, a w ramach PTTK na ekoturystykę.

Aby jednoznacznie rozumieć pierwszą z tych idei, trzeba najpierw wyjaśnić, że autorka definiuje krajoznawstwo jako działalność społeczną oraz dyscyplinę naukową, które mają na celu:

1) pogłębianie od najmłodszych lat więzi ze stronami rodzinnymi i całą ojczyzną;

2) gromadzenie i syntetyzowanie wiadomości o kraju, jego regionach i miejscach;

3) upowszechnianie dziedzictwa natury i kultury w warunkach kameralnych i terenowych przez szkoły, środki społecznego przekazu i organizacje społeczne;

4) kreowanie postaw obywatelskich na zasadzie: poznaj - zrozum - pokochaj - ochroń - rozwiń!.

Konkretyzacja każdego z tych celów przedstawiona jest we wcześniejszej pracy autorki (PISARSKA 2011, s. 97-110). Ze względu na rozśrodkowanie mediów i powszechność szkolnictwa, dziś - tak jak w okresie działalności KEN oraz w XX-leciu międzywojennym - istnieje konieczność podniesienia znaczenia krajoznawstwa w szkołach wszystkich szczebli. Nie wymaga to wcale tworzenia specjalnego przedmiotu w szkołach podstawowych, gimnazjach i liceach, lecz zintegrowanego podejścia nauczycieli przyrody, geografii, historii, biologii oaz języka polskiego do przygotowania zarówno krótszych, jak i dłuższych szkolnych wycieczek krajoznawczych. Zaś odnośnie do kształcenia przyszłych organizatorów turystyki oraz nauczycieli, szczególnie geografii czy historii, istnieje wręcz konieczność podniesienia rangi takich przedmiotów, jak krajoznawstwo i geografia turystyczna Polski.

Autorka, czerpiąc inwencję z pracy Z. KRUCZKA, A. KURKA, M. NOWACKIEGO (2010, s. 166), proponuje, aby nauczyciele i przewodnicy przesycanie turystyki treściami krajoznawczymi próbowali realizować zgodnie z celami interpretacji dziedzictwa, którymi są:

1) wyjaśnienie genezy, np. określonego zjawiska przyrodniczego lub kulturowego; 
2) ułatwienie zrozumienia sensu danego miejsca; objaśnienie jego znaczenia;

3) uwrażliwienie na otoczenie, na jego kompleksowy odbiór;

4) wskazanie na różne uwarunkowania pewnych wydarzeń, zjawisk czy procesów;

5) przybliżenie zależności pomiędzy wybranymi obiektami czy zjawiskami;

6) przekazanie wzorców zachowań wobec środowiska przyrodniczego, kulturowego oraz społecznego.

Zakresy celów krajoznawstwa, interpretacji dziedzictwa pokrywają się z wyznacznikami ekoturystyki, którą autorka definiuje poprzez jej cechy; trzeba je odnieść do:

a) człowieka jako jej uczestnika; są to:

- postawa otwartości na bezpośredni kontakt z przyrodą i kulturą odwiedzanego obszaru;

- aktywność fizyczna (wędrówka) i intelektualna (poznanie, rozumienie);

b) organizacji turystyki; są to:

- zrównoważone korzystanie z zasobów środowiska przyrodniczo-kulturowo-społecznego;

- mała skala ruchu i infrastruktury turystycznej;

- wykorzystywanie każdej okazji do edukacji ekologicznej uczestników.

Ekoturystyką można więc nazwać wiele form turystyki, pod warunkiem, że są one realizowane w sposób przyjazny dla środowiska zarówno przyrodniczego, jak kulturowego. I tak, ze względu na cel należałoby wymienić tu turystykę poznawczą (krajoznawczą), a szczególnie turystykę przyrodniczą. Z nimi zaś mogą (ale nie zawsze tak jest) wiązać się różne formy turystyki kwalifikowanej (piesza, rowerowa, kajakowa, żeglarska, konna itd.). Ekoturystyka w istocie nawiązuje do krajoznawstwa $\mathrm{z}$ okresu pionierskiego, a jej „być albo nie być" zależy od pozycji ochrony przyrody w państwie, $\mathrm{w}$ odbiorze społecznym i w gronie decydentów od turystyki (PISARSKA 2006), s. 35-39, 50-51; 179-182). Ze względu na zasługi PTTK na polu ochrony przyrody ojczystej organizacja ta od dawna realizuje ekoturystykę, a sprzyja temu coraz większy udział uczestników imprez turystyki kwalifikowanej w liczbie uczestników wszystkich imprez (tab. 1.)

Ekologizacja turystyki masowej polega na minimalizowaniu zagrożeń dla środowiska przyrodniczo-kulturowo-społecznego ze strony zagospoda- 
rowania i ruchu turystycznego. Aby była ona możliwa, należy zadbać o stworzenie systemu ogniw edukacji ekologicznej i o formację nie tylko przyszłych kadr turystyki, ale turystów, czego dotyczyły wcześniejsze prace autorki (PISARSKA 2006, s. 35-39, PISARSKA 2008, s. 179-187).

Konkludując przesłanie zamieszczone $\mathrm{w}$ tytule niniejszej pracy nie trzeba daleko szukać, aby znaleźć idee dla współczesnych i przyszłych działań w zakresie turystyki. Warto nie tylko przy okazji jubileuszy oglądać się w przeszłość, uznać genialność pomysłów luminarzy krajoznawstwa i kontynuować je, doskonaląc poprzez adaptację do realiów, co wcale nie oznacza minimalistycznego podejścia. Mając za wzór dawniej i współcześnie żyjących, trzeba nam działać na swoim poletku tak, aby stanowić "ogniwa pośrednie między starymi a nowszymi czasy", co zagwarantuje ciągłość idei krajoznawczej w sztafecie pokoleń. Powinniśmy czerpać ze źródeł mocy, jaką stanowią dzieła naszych poprzedników, ale też służba dla przyrody i ojczyzny poprzez naukę i pracę codzienną.

\section{BIBLIOGRAFIA}

CZARNOWSKI A., 2006, Stynni krajoznawcy, ZG PTTK, Warszawa.

KRUCZEK Z., KUREK A., NOWACKI M., 2010, Krajoznawstwo. Teoria i metodyka, Proksenia, Kraków.

KULCZYCKI Z., 1977, Zarys historii turystyki w Polsce, Sport i Turystyka, Warszawa.

Polska. Zarys encyklopedyczny, 1974, PWN, Warszawa.

LEWAN M., 2004, Zarys dziejów turystyki w Polsce, Proksenia, Kraków.

LIPNIACKI W., 1985, Elementy teorii krajoznawstwa, t. 1, ZW PTTK, Szczecin.

ŁUKASZEWICZ J., 1980, Jan Matejko. Poczet królów i ksiażąt polskich, KAW, Warszawa.

PISARSKA B., 2006, Możliwości edukacji przyrodniczo-kulturowej na obszarach chronionych w Polsce, „Turyzm", 16/1, s. 35-39.

PISARSKA B., 2008, Czynniki ksztattujące nowych zwolenników ekoturystyki w Polsce, [w:] A. Gotowt-Jeziorska, J. Śledzińska (red.), Turystyka zrównoważona i ekoturystyka, Wyd. PTTK „Kraj”, Warszawa, s. 179-187.

PISARSKA B., 2011, Propozycja programu wsparcia rodzin w poznawaniu swojego kraju [w:] J. ŚLEDZIŃSKA, B. WŁODARCZYK (red.), 2012, Turystyka rodzinna a zachowania prospoteczne, Wyd. PTTK „Kraj”, Warszawa, s. 97-110.

Roczniki statystyczne, 1951-2013, GUS, Warszawa.

Statystyka turystyki 1950-1966, ser. „Studia i Prace Statystyczne”, nr 7, GUS, Warszawa.

http:/ / ludzietworzaswiat; 30.03.2014.

http://www.muzeum.szczecin.pl; 30.03.2014.

pl.wikipedia.org/wiki/Idea; 31.03.2014. 


\section{IN SEARCH OF IDEA OF TOURISM DEVELOPMENT “PAST FOR FUTURE”}

Key words: sightseeing, ideas of tourism development

\section{Summary}

Motto of "Past for Future" is displayed at the doorway to the first Polish museum which was established in Puławy in 1801. Reflexion on the sense and actuality of those words caused the need of discussion on the following subjects:

1) Merits of prominent personalities' towards idea of cognition of homeland during the repartition times;

2) Popularization of tourism through activities of tourism associations;

3) Instance of tourism development in $21^{\text {st }}$ century.

Personalities presented in the article joined old and new times; that was a guarantee of continuation of the ideas among generations. There were 200 thousand young tourists educated at schools in 1918-39. After 1950 the main role played the PTTK. This organization had 767.9 thousand members in 1979 and 10.9 million participants of its excursions and events.

The Author proposes the following main ideas of tourism development in $21^{\text {st }}$ century:

1) Continuance of the substance of tourism which is the sightseeing value presented in accordance with the goals of the heritage interpretation;

2) Ecologization of mass tourism and development of ecotourism within PTTK. 